of the same as their birth sex) could decrease under the new name (especially given the male connotations of the word 'king'), and that related health care could suffer. I acknowledge the potential downsides, but think that these would be outweighed by improvements in care that could follow. The name could help people to understand that their cancer risk is not limited to breast and ovarian cancer. It might also help them to better communicate the risks to their family members, or to a new health-care provider, and so increase the chance that testing is done.

Renaming HBOC could even spark a wider discussion around confusing names for cancer genetic syndromes. Hereditary diffuse gastric cancer syndrome, for instance, is caused chiefly by inherited mutations in $C D H 1$, which encodes a protein that helps to establish and maintain the shape of epithelial cells, such as those found in the gut lining. People with these mutations are much more likely than the general population to develop a certain type of breast cancer ${ }^{11}$, and the children of families with this syndrome are at risk of having some types of congenital malformation, such as a cleft lip ${ }^{12}$.

Ultimately, using names that are simple and flexible, instead of obtuse and out of step with emerging understanding, could save lives by improving communication and awareness. -

Colin C. Pritchard is associate professor in the Department of Laboratory Medicine, University of Washington, and head of precision diagnostics at the Brotman Baty Institute for Precision Medicine, Seattle, Washington, USA. He is a colleague of Mary-Claire King. e-mail:cpritch@uw.edu

1. Childers, K. K., Maggard-Gibbons, M., Macinko, J. \& Childers, C. P. JAMA Oncol. 4 876-879 (2018).

2. Rauscher, E. A., Dean, M. \& Campbell-Salome, G. M. J. Genet. Couns. 27, 1417-1427 (2018).

3. Strømsvik, N., Råheim, M., Øyen, N., Engebretsen, L. F. \& Gjengedal, E. J. Genet. Couns. 19, 360-370 (2010)

4. Antoniou, A. C. et al. N. Engl. J. Med. 371, 497-506 (2014).

5. Castro, E. et al. J. Clin. Oncol. 31, 1748-1757 (2013).

6. Mateo, J. et al. N. Engl. J. Med. 373, 16971708 (2015).

7. Na, R. et al. Eur. Urol. 71, 740-747 (2017).

8. Pritchard, C. C. et al. N. Engl. J. Med. 375, 443-453 (2016)

9. National Comprehensive Cancer Network. Genetic/Familial High-Risk Assessment: Breast and Ovarian Version 2.2019 (2019).

10.Lynch, H. T., Snyder, C. L., Shaw, T. G., Heinen, C. D. \& Hitchins, M. P. Nature Rev. Cancer 15, 181-194 (2015).

11. Hansford, S. et al. JAMA Oncol. 1, 23-32 (2015).

12.Figueiredo, J. et al. J. Med. Genet. 56 199-208 (2019).

13. Hall, J. M. et al. Science 250, 1684-1689 (1990).

14.King, M. C. Science 343, 1462-1465 (2014).

15.King, M. C., Levy-Lahad, E. \& Lahad, A. J. Am. Med. Assoc. 312, 1091-1092 (2014).

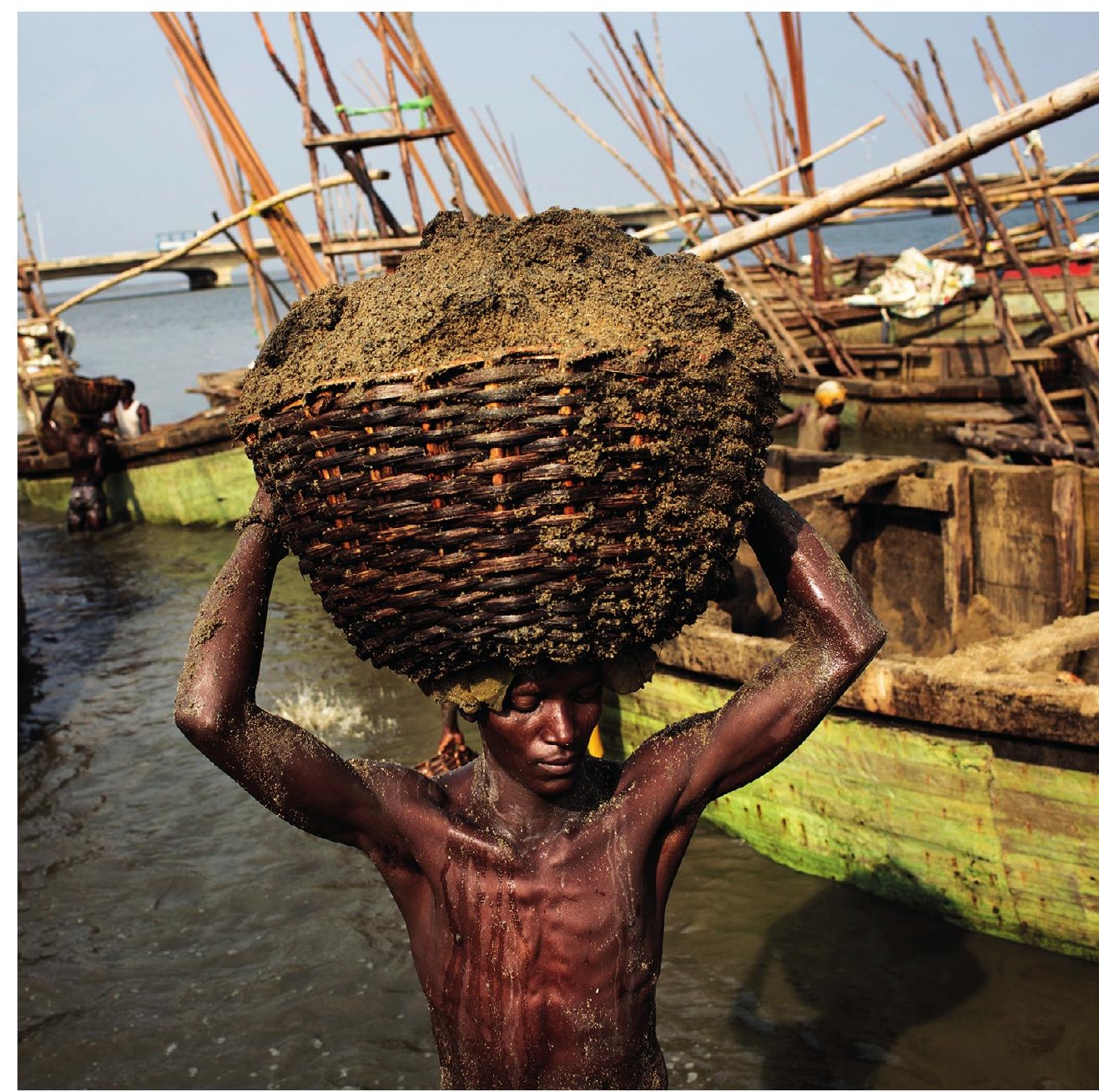

In Lagos Lagoon in Nigeria, labourers dig sand from the sea floor by hand.

\section{Time is running out for sand}

$\mathrm{W}$ hat links the building you live in, the glass you drink from and the computer you work on? Sand. It is a key ingredient of modern life and yet, astonishingly, no-one knows how much sand there is or how much is being mined.

Sand and gravel make up the most extracted group of materials, even exceeding fossil fuels ${ }^{1}$. Urbanization and global population growth are fuelling an explosion in demand, especially in China, India and Africa ${ }^{2}$. Roughly 32 billion to 50 billion tonnes are used globally each year, mainly for making concrete, glass and electronics ${ }^{3}$.
This exceeds the pace of natural renewal ${ }^{4}$ such that by mid-century, demand might outstrip supply ${ }^{2}$ (see 'Global scarcity'). A lack of knowledge and oversight is allowing this unsustainable exploitation.

Desert sand grains are too smooth to be useful, and most of the angular sand that is suitable for industry comes from rivers (less than $1 \%$ of the world's land $)^{5}$. This extraction of sand and gravel has far-reaching impacts on ecology, infrastructure and the livelihoods of the 3 billion people who live along rivers $3,6,7$ (see 'Shifting sands'). For example, sand mining on the Pearl River (Zhujiang) in China 
- has lowered water tables, made it harder to extract drinking water and hastened river-bed scour, damaging bridges and embankments ${ }^{7}$.

Most of the trade in sand is undocumented. For example, between 2006 and 2016, less than $4 \%$ of the 80 million tonnes of sediment that Singapore reported having imported from Cambodia was confirmed as exported by the latter ${ }^{8}$. Illegal sand mining is rife in around 70 countries $^{3}$, and hundreds of people have reportedly been killed in battles over sand in the past decade in countries including India and Kenya, among them local citizens, police officers and government officials.

All these problems have been highlighted in reports from the wildlife charity WWF and the United Nations Environment Programme (UNEP), questioning the sustainability of sand extraction ${ }^{3,6}$. The underlying reasons are too few data and a lack of policies supporting responsible consumption and extraction.

We now call on UNEP and the World Trade Organization (WTO) to set up and oversee a global monitoring programme for sand resources. Researchers need to establish accounting processes for sand flows in, and sand extraction from, rivers - both legal and illegal. They need to bring the scale of the problem starkly to the attention of their peers, the public and policymakers. Local sand budgets and measures to promote responsible use must then be developed.

\section{SCANT DATA}

Current estimates of global sand mining are unreliable and undoubtedly too low. Most research on river sediment has focused on how dams block flows, and little academic attention has been given to commercial extraction ${ }^{1,4}$. For example, as of early 2019 , we found that only 38 of 443 scientific papers on sand mining identified in a search of the Web of Science quantified the amount of sand being extracted.

There are few long-term, basin-wide programmes monitoring sediment. It is technically hard to quantify how sand moves or is deposited along rivers. In addition, many large rivers are remote, and politically and industrially sensitive issues of data access and transparency hamper reporting.

Many large river basins also span several countries, making it difficult to report and enforce regulations and international laws. For example, the Mekong River flows through China, Myanmar, Laos, Thailand, Cambodia and Vietnam.

In many countries, sand mining is unregulated and might involve local 'sand mafias'. Methods of extraction range from dredging boats and suction pumping to digging with shovels and bare hands, both in daylight and during the night. In the developing world, where demand is greatest ${ }^{2}$, it is mainly a small, informal industry, which is difficult to monitor and control. The source of sand dredged from rivers is hard to pinpoint, compared with that of material dug from shallow river beds and floodplain quarries.

International sand-trade databases are too crude to track sustainability. The global UN Comtrade database, for example, collates the export and import values of sand and gravel in one or two categories, based around the quality and composition of material. It does not distinguish between sand taken from rivers and deltas that are being replenished (active sources) and sand removed from passive sources that are not, such as geological deposits.

Extraction of sand and gravel from active sources can cause great environmental,

\section{SHIFTING SANDS}

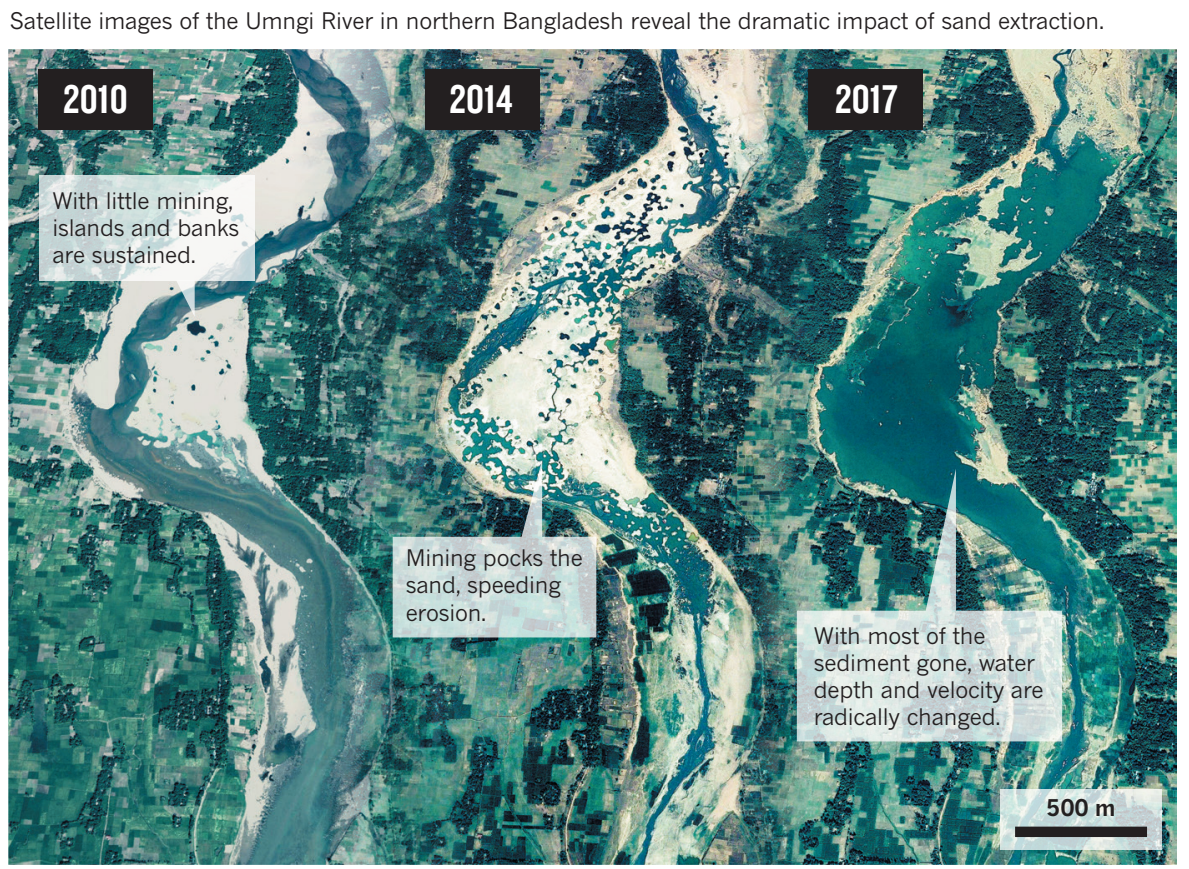

social and economic harm, whereas extraction from passive sources has fewer environmental impacts. For example, in the Mekong delta, the Vietnamese government estimates that nearly 500,000 people will need to be moved away from river banks that are collapsing as a result of sand mining in the channel. In the Ganges River in northern India, eroded river banks have destroyed the nesting and breeding habitats of fish-eating gharial crocodiles (Gavialis gangeticus), a critically endangered species with only around 200 adults left in the wild in northern India and Nepal.

\section{GLOBAL AGENDA}

The following seven components are essential for sustainable sand extraction.

Source. Sustainable sources of sand - such as the sand being gradually added to the coast in Greenland by the retreating ice sheet ${ }^{9}$ must be sought and certified. The UN needs to develop a plan, perhaps along the lines of sustainable forestry management. New passive sources of sand should be identified that do not damage rivers. These might include deposits locked up in floodplain sediments that can be quarried. Or sand trapped behind dams might be extracted with less ecological impact than mining downstream.

Replace. Local and national governments and planning authorities should encourage greater use of alternatives to sand, such as crushed rock, industrial slag and waste (including copper, fly ash and foundry sand $^{3,6}$ ) and recycled plastic. For example, roads, car parks and driveways made from plastic waste embedded in asphalt can lessen demand for bitumen and aggregate.

Reuse. Sand-based materials should be reused when possible. For example, demolition waste and concrete can be crushed and mixed into cement. Rubble can be used as a base aggregate for building foundations and roads, for filling holes and as gravel for walkways, gardens, noise barriers and embankments. Legislation and controls on the disposal of concrete, and financial incentives to reuse old concrete, will be needed.

Reduce. Cutting the amount of concrete required in new structures would also lessen the demand for sand ${ }^{3}$. This could be achieved by using more efficient materials (such as concrete blocks and printed construction panels with hollow cores). Industry standards for material qualities will be needed and should be backed up by regulations to enforce usage.

Govern. An international or multilateral framework ${ }^{6}$ to regulate and control sand extraction should be forged between local stakeholders, non-governmental organizations, industry, law enforcers and 
